\title{
DESIGN AND PERFORMANCE OF A MIXED SEDIMENT NOURISHMENT PROJECT ALONG AN URBAN SEDIMENT-STARVED SHORELINE
}

\author{
John Ramsey, Applied Coastal Research and Engineering Inc., jramsey@appliedcoastal.com \\ Sean Kelley, Applied Coastal Research and Engineering Inc., skelley@appliedcoastal.com \\ Rebecca Quan, Applied Coastal Research and Engineering Inc., rquan@appliedcoastal.com
}

\section{PROJECT BACKGROUND}

The long-term shore protection of Boston's open ocean shoreline has utilized a variety of coastal engineering strategies to prevent or at least inhibit the impacts of coastal flooding and storm wave action to urban development. The Winthrop Beach region is located to the north of the Boston Harbor entrance and historically incorporated a variety of coastal engineering structures, beginning in the late $1880 \mathrm{~s}$, to mitigate the impacts of coastal flooding and storm wave action. To some degree, these "hard" shore protection measures have prevented further degradation of upland infrastructure; however, loss of the littoral sediment supply due to coastal armoring of the adjacent upland and the related lowering of the beach fronting the seawall along the length of Winthrop Beach have increased the storm damage potential of the community protected by these structures. Recent, relatively minor northeast storms have caused significant damage to the seawall originally constructed in 1899, requiring temporary stabilization to prevent failure of the wall and the adjacent roadway.

Winthrop Beach faces the open ocean, is approximately 2,100 meters in length, and is situated along the east side of Winthrop between two glacial headlands or relic drumlins. To address the issues of shore protection and "sediment starvation" along the Winthrop Beach shoreline, a beach nourishment project has been designed to return the shoreline to historic conditions.

\section{PROJECT DESIGN}

Unlike most beach nourishment projects in the United States, the material proposed for restoration of Winthrop Beach consists of mixed cobble, gravel, and sand sediments. Due to the origin of the native beach (erosion of glacial drumlin deposits), the in situ beach material consists of poorly sorted materials ranging from fine sand to cobble. The total beach fill length was approximately 1,300 linear meters and the equilibrated berm width is designed at 30 meters. The total nourishment volume was approximately $350,000 \mathrm{~m}^{3}$. Once the beach nourishment was completed in late 2014 , the high tide shoreline was pushed more than 45 meters from the seawall, with a gradual slope extending approximately 110 meters offshore. Although shoreline change modeling indicated a design life of approximately 10 years, it is anticipated that the coarse fraction of the nourishment material will be naturally sorted by wave action and form a gravel/cobble berm along the upper portion of the beach (observed along the natural mixed sediment beaches of the New England coast). Initial monitoring results after the first complete year postnourishment support this finding, as minimal sediment loss has occurred, despite an active nor'easter season in the winter of 2014-2015.

To ensure that severe nor'easters cannot overtop the beach, the fill elevation was brought up to an elevation that was nearly the height of the sidewalk; a fill height of more than 6 meters in some areas. In addition, the sandy borrow material from an upland source in nearby Saugus was mixed with gravel and cobble from other locations in Massachusetts to ensure that beach material would perform in a similar fashion to the native beach.

\section{PREDICTED BEHAVIOR AND PERFORMANCE}

The larger sediments (gravel and cobble) tend to perform differently than the finer-grained (sandy) material during a storm, forming an erosion-resistant ridge on the beach face. During Winter Storm 'Juno' in 2015, the beach performed as designed, with adjustment of the beach shape caused by the severe wave conditions. Formation of a steep 'cobble' berm along the face of the beach was successful in dissipating the storm wave energy associated with the storm.

As suggested by Kamphuis (1990), longshore transport is proportional to $\left(D_{50}\right)^{-0.25}$, where $D_{50}$ is the median grain size of the beach material; therefore, use of mixed sediment (a combination of sand, gravel, and cobble) on Winthrop Beach could extend the design life of the nourishment by as much as three or four times the longevity of a sand fill project. To evaluate fill performance, a shoreline change model was developed utilizing both the immersed weight sediment transport formulation described by Kamphuis (1990), as well as a cobble transport equation. Cobble transport was calculated using the method of Van Wellen, et al. (2000). The transport equation proposed by Van Wellen, et al., is specifically formulated for cobble beaches, and includes a sediment movement threshold term as well as transport in the swash zone, both of which are important for beaches of this type.

Losses over the first two storm seasons were minor (less than $15 \%$ loss within the project 'footprint') and ongoing shoreline and beach volume monitoring, combined with the mixed sediment transport modeling analysis, are aimed at developing a more complete understanding of mixed-sediment nourishment longevity in this wave and tide (greater than 3 meter average tide range) environment.

\section{REFERENCES}

Kamphuis, $1990 . \quad$ "Sediment Transport Rate." Proceedings of $22^{\text {nd }}$ International Coastal Engineering Conference. ASCE.

Van Wellen, Chadwich and Mason (2000). "A Review and Assessment of Longshore Sediment Transport Equations for Coarse-Grained Beaches." Coastal Engineering, 40, pp. 243-275. 